\author{
П. О. Попков \\ здобувач \\ Інституту еконоліко-правових досліджень \\ Національної академії наук України
}

\title{
ЗАСТОСУВАННЯ МИРОВОЇ УГОДИ У ПРОЦЕДУРІ БАНКРУТСТВА В УМОВАХ ОНОВЛЕНОГО ЗАКОНОДАВСТВА
}

Постановка проблеми. Економічна та фінансова криза, падіння обсягів попиту, низька інвестиційна активність та інші несприятливі економічні умови призвели до того, що ситуація, яка склалася в сучасний період, не відрізняється стабільністю, і практично у будь-якого суб'єкта господарювання або громадянина можуть виникнути фінансові складності або заборгованості.

Ринкова економіка є складною системою взаємопов'язаних і взаємодіючих між собою різних суб'єктів господарювання, громадян і держави. Діяльність як суб'єктів господарювання, так і держави в умовах інтеграційних процесів в Україні змінилася. Окремі учасники ринкових відносин, які не в змозі виконувати свої зобов'язання в умовах жорсткої конкуренції, стають банкрутами. Неспроможність таких суб'єктів викликає негативні наслідки не тільки для самого суб'єкта, а також для його контрагентів, кредиторів і держави взагалі. Крім того, неспроможність суб'єктів викликає негативні соціальні наслідки для працівників і їх сімей.

Процедура банкрутства є не тільки невід’ємною частиною ринкового механізму, об'єктивно зумовленим результатом функціонування цього механізму, а також одним із регуляторів економічних процесів у суспільстві шляхом забезпечення стабільності господарського обігу.

Необхідність дослідження застосування мирової угоди у процедурі банкрутства обгрунтовується тим, що сьогодні спостерігається різке збільшення кількості неплатоспроможних суб'єктів господарювання. За нинішніх умов економічної кризи процедура банкрутства спонукає підвищувати ефективність використання виробничих ресурсів.

Мирова угода $є$ одним із засобів запобігання банкрутству боржника, відновлення його платоспроможності, врегулювання майнових розбіжностей із кредиторами. Роль мирової угоди неможливо переоцінити, але процес укладення мирової угоди ускладнюється не тільки відсутністю теоретичних розробок, а також неузгодженістю, протиріччям деяких правових норм. У сучасний період Україна продовжує перебувати у стані реформування законодавства про банкрутство. Із 21 жовтня 2019 р. втрачає свою дію Закон України «Про відновлення платоспроможності боржника або визнання його банкрутом» (далі - Закон) і набуває чинності Кодекс України з процедур банкрутства (далі - Кодекс). Порівняно із Законом Кодекс є більш прогресивним нормативним актом, містить логічно виважену систему понять і категорій, структурованість процесу тощо. Але поряд із позитивними сторонами цей акт має ряд спірних питань, прогалин або невідповідностей, у т.ч. щодо мирової угоди. Тому це дослідження присвячено аналізу питання стосовно укладення мирової угоди у процедурі банкрутства.

Метою статті є дослідження проблем як теоретичного, так і практичного характеру щодо застосування мирової угоди у процедурі банкрутства в умовах оновленого законодавства.

Аналіз останніх досліджень і публікацій. Деякі питання мирової угоди в національному судочинстві були предметом дослідження таких вчених, як З. Будько, Б. Гриняк, С. Заболотній, В. Радзивілюк, Д. Соболєв, Г. Пронська, Т. Шевченко та ін. Місце мирової угоди у процедурі банкрутства досліджували Р. Афанасьєв, О. Бірюков, В. Джунь, В. Малига, Б. Поляков, Е. Сгара, М. Тітов та інші вчені.

Виклад основного матеріалу. Метою банкрутства є не знищення суб'єкта господарювання, якщо це не рейдерські схеми, а збереження та відновлення платоспроможності. Тому в інтересах боржника запропонувати такий засіб погашення заборгованості, на який погодяться кредитори.

Закон України «Про відновлення платоспроможності боржника або визнання його банкрутом» містить різні засоби вирішення спору на підставі договірних відносин. Одним із таких засобів, спрямованим на не ліквідаційні процедури, є мирова угода. Слід підкреслити, що не ліквідаційні процедури, до яких належить ще санація, порівняно з ліквідацією, більш ефективні, але, незважаючи на це, вони рідко використовуються на практиці.

Закон України «Про відновлення платоспроможності боржника або визнання його банкрутом» - єдиний нормативний акт, який надає поняття мирової угоди. Ст. 77 визначає мирову угоду як домовленість між боржником і кредиторами стосовно відстрочки та/або розстрочки, а також прощення (списання) кредиторами боргів боржника, яка оформляється шляхом укладення угоди між сторонами [1]. Тобто сутність мирової угоди полягає у припиненні провадження у справі про 
банкрутство шляхом визначення положень, спрямованих на врегулювання обов'язків неплатоспроможного боржника щодо погашення заборгованості його кредиторам будь-якими законними засобами.

Є.Ю. Олевінський підкреслює, що ознаки мирової угоди визначаються: процедурою банкрутства; ця процедура укладається з метою вирішення питань порядку, способів і строків розрахунків боржника 3 кредиторами; угода є підставою про припинення провадження у справі про банкрутство [2, с. 6].

Характерні риси мирової угоди повинні відображати їі сутність, значення для учасників процедури примирення, а також специфіку та загальноправову роль як процедури, що застосовується до неплатоспроможного боржника. Виділяють такі ознаки мирової угоди: укладається в письмовій формі; може укладатися на будь-якій стадії процедури банкрутства; вступає в законну силу із дня затвердження її господарським судом; не допускається внесення змін і їі розірвання сторонами без рішення господарського суду; недійсність і розірвання мирової угоди є підставою поновлення провадження у справі про банкрутство щодо вимог незадоволених кредиторів; рішення про укладення приймається не всіма кредиторами, а більшістю; умови її виконання є добровільними i не вимагають виконавчих документів суду; за наявності відповідних підстав її можна розірвати або визнати недійсною; у разі її недійсності чи розірвання може поновитися провадження у справі про банкрутство [3, с. 68-69].

Мирова угода $є$ гнучким інструментом, що дозволяє на партнерських i взаємовигідних засадах врегулювати відносини боржника і кредиторів. Мирова угода - це оптимальний засіб вирішення спору, з одного боку, спрямована на задоволення інтересів кожної сторони, тобто вона захищає приватні інтереси, з іншого - зберігається суб'єкт господарювання, боржник продовжує свою діяльність, тобто мирова угода спрямована на захист публічного інтересу та задоволення інтересів держави.

Інститут мирової угоди є договором між неплатоспроможним боржником і кредитором, який спрямований на врегулювання між ними кредиторської заборгованості. Це може бути збільшення термінів погашення грошових зобов'язань, зниження суми боргу, прощення або списання боргу тощо [3, с. 69]. Практика застосування інституту мирової угоди свідчить, що така угода може бути знаряддям для реалізації боржником своїх протиправних інтересів, у зв'язку з чим законодавцем передбачена відповідальність (у т.ч. й кримінальна), зокрема за фіктивне банкрутство, приховання банкрутства, умисне доведення до банкрутства (ст. 215 ГК України [4], ст. 219 Кримінального кодексу України [5]).

Закон зазначає, що мирова угода може бути укладена на будь-якій стадії провадження у справі про банкрутство. У процедурі розпорядження майном боржника мирову угоду може бути укладено лише після виявлення всіх кредиторів і затвердження господарським судом реєстру вимог кредиторів. Мирова угода укладається у письмовій формі та підлягає затвердженню господарським судом, про що зазначається в ухвалі господарського суду про припинення провадження у справі про банкрутство. Мирова угода набирає чинності 3 дня iĭ затвердження господарським судом і є обов'язковою для боржника (банкрута), кредиторів, вимоги яких забезпечені заставою, кредиторів другої та наступних черг [1]. На підставі Закону процедура затвердження мирової угоди відповідає такому порядку:

1. Затвердження судом мирової угоди або відмови в цьому (до заяви додаються: текст угоди; протокол засідання комітету кредиторів, на якому було прийняте рішення про укладання мирової угоди; список кредиторів із зазначенням їх реквізитів і суми заборгованості; зобов'язання боржника про відшкодування всіх витрат (маються на увазі першочергові вимоги); письмові заперечення кредиторів (якщо такі були).

2. Призначення судом дати розгляду мирової угоди та повідомлення про це сторони.

3. Проведення засідання суду. На засіданні заслуховуються присутні кредитори.

4. Подання до суду заяви про затвердження мирової угоди (протягом 5 днів із дня її підписання сторонами) [6, с. 63].

Але описаний механізм укладення мирової угоди діє до 21 жовтня 2019 р., доки діє Закон, надалі починає діяти Кодекс, який взагалі не містить положень щодо укладення мирової угоди. Слід зазначити, що законодавство про банкрутство потребувало удосконалення, про це свідчить велика кількість змін до законодавства про банкрутство.

Питання банкрутства, а точніше неплатоспроможності юридичної особи та фізичної особи - підприємця врегульовано доволі непогано і не дуже великою кількістю нормативних актів, щоб це питання потребувало кодифікації. Зокрема, це питання врегульовано Законом України «Про відновлення платоспроможності боржника або визнання його банкрутом», Законом України «Про виконавче провадження», Законом України «Про нотаріат», «Про державну реєстрацію речових прав на нерухоме майно та їх обтяжень», Господарським кодексом України, Господарським процесуальним кодексом України, Цивільним кодексом України, Цивільним процесуальним кодексом України [7].

Проект Кодексу України з процедур банкрутства обговорювався юридичною спільнотою протягом тривалого періоду та був ухвалений із деякими зауваженнями. Не всі положення нового законодавчого акта позитивно сприймаються. Крім того, сам факт його затвердження деякі вчені називають великим кроком вперед, інші мають цілковито 
протилежну думку. Одним із нововведень є скасування мирової угоди. Ї̈̈ елементи розглядатимуться як складові частини плану санації, адже відповідно до ч. 2 ст. 51 Кодексу останній може містити такий захід щодо відновлення платоспроможності боржника, як відстрочення, розстрочення або прощення боргу чи його частини [8].

Ст. 212 Господарського кодексу України (далі - ГК) зазначає, що у випадках, передбачених законом, щодо неплатоспроможного боржника застосовується мирова угода [4]; ст. 192 Господарського процесуального кодексу України (далі - ГПК) містить норми щодо укладення мирової угоди з метою врегулювання спору на підставі взаємних поступок і має стосуватися лише прав та обов'язків сторін [9].

Тобто нині можливість укладення мирової угоди залишається на підставі статей ГК і ГПК, що зводить можливість їі укладання нанівець через існування особливостей механізму укладання, що був прописаний у Законі. Положення, які передбачає Кодекс, у процесі санації не можуть бути аналогом мирової угоди.

Висновки. На підставі вищевикладеного можна зазначити, що відсутність положень, спрямованих на укладення мирової угоди, негативно позначаться на правах та інтересах як боржника, так і кредиторів. Пропонується доповнити Кодекс України з процедур банкрутства розділом, який міститиме норми щодо укладення мирової угоди у процесі банкрутства.

\section{Jimepamypa}

1. Про відновлення платоспроможності боржника або визнання його банкрутом: Закон України від 14 травня 1992 № 2343-XII. URL: http://zakon.rada.gov.ua/ laws/show/2343-12/card2 \#Card (дата звернення: 05.06.2019).

2. Олевинский Э.Ю. Мировое соглашение. Чер ные дыры в российском законодательстве. 2002. № 3 . C. 257-286. URL: http://www.k-press.ru/bh/2002/3/ olevinsky/olevinsky.asp. (дата звернення: 05.06.2019).

3. Шапіро B.С., Сердюк В.I. Мирова угода: особливості та правове регулювання. Правова інфорлатика. 2015. № 2 (46). С. 67-72.

4. Господарський кодекс України : Закон України від 16 січня 2003 р. № 436-IV. Відомості Верховної Ради України. 2003. № 18-22. Ст. 144.

5. Кримінальний кодекс України : Закон України від 05 квітня 2001 р. № 2341-III. Відомості Верховної Ради України. 2001. № 25-26. Ст. 131.

6. Ноур Т. Мирова угода у справі про банкрутство. Бібліотека Баланс. Банкрутство. 2005. № 11. С. 61-68.

7. Кравець Р. Банкрутство по новому. АӘво катська компанія «Кравець та партнери». URL: https://knpartners.com.ua/bankrutstvo-po-novomu/ (дата звернення: 05.06.2019).

8. Дутковський Б. Кодекс про банкрутство: що підписав президент I чому стати банкрутом це ще не кінець фінансової історії. Mind. URL: https://mind.ua/openmind/20196137-kodeks-probankrutstvo-shcho-pidpisav-prezident (дата звернення: 05.06.2019).
9. Господарський процесуальний кодекс України : Закон України від від 06 листопада 1991 р. № 1798-XII. Офіиійний веб-портал Верховної Ради України. URL: http://zakon2.rada.gov.ua/laws/show/1798-12 (дата звернення: 05.06.2019).

\section{Анотація}

Попков П. О. Застосування мирової угоди у процедурі банкрутства в умовах оновленого законодавства. - Стаття.

У статті проведено дослідження теоретичних підходів до застосування мирової угоди у процедурі банкрутства. Автор розглядає мирову угоду в процедурі банкрутства в умовах оновленого законодавства. Мету зазначеного дослідження досягнуто за допомогою авторського аналізу нормативних актів і звернення до відповідних наукових праць окремих фахівців. Визначено, що мирова угода є одним із засобів запобігання банкрутству боржника, відновлення його платоспроможності, врегулювання майнових розбіжностей із кредиторами. Мирова угода - це оптимальний засіб вирішення спору, з одного боку, спрямований на задоволення інтересів кожної сторони, тобто він захищає приватні інтереси, з іншого - зберігається суб’єкт господарювання, боржник продовжує свою діяльність, тобто мирова угода спрямована на захист публічного інтересу та задоволення інтересів держави.

Визначено, що сутність мирової угоди полягає у припиненні провадження у справі про банкрутство шляхом визначення положень, спрямованих на врегулювання обов'язків неплатоспроможного боржника щодо погашення заборгованості його кредиторам будь-якими законними засобами.

Проаналізовано норми Закону України «Про відновлення платоспроможності боржника або визнання його банкрутом» щодо регулювання укладення мирової угоди та зазначено, що цей закон діє до 21 жовтня 2019 р. Надалі починає діяти Кодекс України з процедур банкрутства, який не містить норми щодо мирової угоди. Тобто нині можливість укладення мирової угоди залишається на підставі статей Господарського кодексу України і Господарського процесуального кодексу України, що зводить можливість ії укладання нанівець через існування особливостей механізму укладання, прописаного у Законі України «Про відновлення платоспроможності боржника або визнання його банкрутом». Положення, які передбачає Кодекс України з процедур банкрутства, у процесі санації не можуть бути аналогом мирової угоди.

Доведено, що відсутність положень, спрямованих на укладення мирової угоди, негативно позначаться на правах та інтересах як боржника, так і кредиторів. Пропонується доповнити Кодекс України з процедур банкрутства розділом, який міститиме норми щодо укладення мирової угоди у процесі банкрутства.

Ключові слова: банкрутство, мирова угода, господарський спір, господарський суд, господарське судочинство.

\section{Summary}

Popkov P. O. Application of the settlement agreement in the bankruptcy procedure under the terms of the updated legislation. - Article.

The article deals with the study of theoretical approaches to the application of the settlement agreement in the bankruptcy procedure. The author considers the settlement agreement in the procedure of bankruptcy under the terms of the updated legislation. The purpose of this study was achieved through the author's analysis of 
normative acts and the reference to the relevant scientific works of individual specialists. It is determined that the agreement is one of the means of preventing the debtor's bankruptcy, restoring its solvency, and resolving property disputes with creditors. A settlement agreement is an optimal means of resolving a dispute aimed at satisfying the interests of each party, that is, it protects private interests, as well as keeps the business entity, the debtor continues his activity, that is, the settlement agreement is aimed at protecting the public interest and satisfying the interests of the state.

The essence of the settlement agreement is defined in the termination of proceedings on bankruptcy by defining provisions aimed at settling the obligations of the insolvent debtor to repay debts to its creditors by any lawful means.

The norms of the Law of Ukraine «On restoring a debtor's solvency or recognizing it bankrupt" are analysed in relation to the regulation of the conclusion of a settlement agreement, and it is indicated that this law is valid until 21.10.2019. In the future the Code of Ukraine on bank- ruptcy procedures, which does not contain norms regarding the settlement agreement, begins to operate. That is, at present, the possibility of concluding a settlement agreement remains on the basis of articles of the Economic Code of Ukraine and the Economic Procedural Code of Ukraine, which reduces the possibility of its nullification due to the existence of the peculiarities of the mechanism of conclusion, which was prescribed in the Law of Ukraine «On restoring a debtor's solvency or recognition of it bankrupt». The provisions of the Code of Ukraine on bankruptcy procedures in the process of sanation cannot be analogous to a settlement agreement.

It is proved that the absence of provisions aimed at concluding an agreement will adversely affect the rights and interests of both the debtor and the creditors. It is proposed to supplement the Code of Ukraine on Bankruptcy Procedures by a section that will contain rules for concluding a settlement agreement in the process of bankruptcy.

Key words: bankruptcy, settlement agreement, economic disputes, economic court, economic legal proceedings. 